ROMAN POLETYŁO

Archiwum UKSW, Warszawa

\title{
DZIALALNOŚĆ ARCHIWUM UNIWERSYTETU KARDYNAŁA STEFANA WYSZYŃSKIEGO W WARSZAWIE W ŚWIETLE JEGO SPRAWOZDAWCZOŚCI W LATACH 2003-2015
}

Archiwum Uniwersytetu Kardynała Stefana Wyszyńskiego w Warszawie (zwane dalej Archiwum UKSW) zostało powołane Zarządzeniem nr 7/2000 Rektora Uniwersytetu Kardynała Stefana Wyszyńskiego w Warszawie z dnia 1 września 2000 r. w sprawie utworzenia Archiwum Uniwersytetu oraz wprowadzenia w życie norm kancelaryjnych i podstawowych dokumentów, regulujących obieg akt uczelni. Tak więc 15-lecie jego istnienia na przekształconym z Akademii Teologii Katolickiej w Warszawie uniwersytecie jest dobrym momentem do zbadania jego działalności. Niezbędna tu jest przede wszystkim wymierna działalność pracowników Archiwum UKSW, a mianowicie sprawozdawczość. Archiwum, jako nadzorowana jednostka, przechowująca m.in. materiały archiwalne, ma bowiem wśród szeregu obowiązków, również zobowiązanie dostarczania corocznie do końca marca do Archiwum Państwowego w Warszawie rocznych sprawozdań z jego działalności. Ale to nie wszystko. Jak autor wykaże poniżej, wśród sprawozdań wytworzonych przez archiwistów w okresie tych 15 lat są także sprawozdania roczne (cząstkowe do rocznych uczelnianych) i wieloletnie powstałe na użytek wewnętrzny, na potrzeby Rektorów i Prorektorów, nadzorujących Archiwum UKSW.

Na wstępie, dla lepszego zrozumienia, należy wykazać specyfikę archiwów szkół wyższych. Archiwum UKSW jest archiwum państwowym o powierzonym zasobie: zawiera zasoby historyczne, ma za zadania gromadzenie, ewidencjonowanie, udostępnianie dokumentacji i przechowywanie swoich zbiorów do czasu istnienia uczelni bez konieczności przekazywania akt do właściwego archiwum państwowego. Istotny jest też jego dydaktyczno-naukowo-badawczy charakter, jaki powinno spełniać.

Zasób Archiwum UKSW stanowi jeden otwarty zespół archiwalny. Gromadzi bowiem, opracowuje i udostępnia akta i Akademii Teologii Katolickiej w Warszawie, i dalej Uniwersytetu Kardynała Stefana Wyszyńskiego w Warszawie. Merytorycznie podlega archiwum państwowemu, jakim jest Archiwum Państwowe w Warszawie. Przez nie jest kontrolowane, tam uzyskuje zgodę na brakowanie dokumentacji już niepotrzebnej, na przekwalifikowanie, ale nie przekazuje tam swoich zasobów.

Archiwum UKSW jest jednostką pozawydziałową Uniwersytetu Kardynała Stefana Wyszyńskiego w Warszawie i podlega bezpośrednio jednemu z prorektorów uczelni. Posiada w swoim zasobie dokumentację z Akademii Teologii Katolickiej w Warszawie (zespół 
archiwalny z lat 1954-1999 - dopływ historyczny istniejący przed utworzeniem Archiwum UKSW - głównie akta studenckie), jak i archiwalia z dopływów z lat po utworzeniu Archiwum UKSW (zespół archiwalny Uniwersytetu Kardynała Stefana Wyszyńskiego w Warszawie od 1999 r. - głównie akta studenckie, akta osobowe pracowników ATK/UKSW, przewody doktorskie, habilitacyjne, postępowania profesorskie, fotografie, filmy, nagrania dźwiękowe). W Archiwum UKSW znajduje się wiele cennej dokumentacji o wartości historycznej, która jest wykorzystywana przez naukowców do badań historycznych o zasięgu węższym, uczelnianym, jak i krajowym a także do innych badań naukowych (służy np. pisarzom, dziennikarzom). Większość stanowią jednak udostępnienia dla potrzeb bieżących administracji (szczególnie dziekanatów).

Przed omówieniem poszczególnych sprawozdań z działalności Archiwum UKSW warto jest jeszcze wykazać jego podstawowe zadania. Ich realizacja znajduje swoje czytelne odbicie właśnie w sprawozdaniach. Te zadania to:

1. przyjmowanie dokumentacji ze wszystkich jednostek organizacyjnych UKSW;

2. przechowywanie dokumentacji we właściwym porządku;

3. ewidencja i opracowywanie posiadanej dokumentacji;

4. prowadzenie działalności informacyjnej (przeprowadzanie kwerend społecznych);

5. wypożyczanie i udostępnianie dokumentacji jednostkom organizacyjnym UKSW;

6. kontrola postępowania $\mathrm{z}$ dokumentacją $\mathrm{w}$ registraturach jednostek organizacyjnych UKSW;

7. nadzór nad tzw. brakowaniem (czyli niszczeniem) dokumentacji niepotrzebnej;

8. uczestniczenie w pracach tzw. Komisji Archiwalnej Oceny Dokumentacji.

W czasie 15 lat istnienia Archiwum UKSW realizację tych zadań dokumentują sprawozdania powstałe w latach 2003-2015 i przedstawione tutaj w porządku chronologicznym:

1. Sprawozdanie z działalności Archiwum UKSW w roku akademickim 2002/2003';

2. Sprawozdanie z działalności Archiwum UKSW w roku akademickim 2003/20042;

3. Sprawozdanie z działalności Archiwum UKSW w roku akademickim 2004/20053;

4. Sprawozdanie z działalności Archiwum UKSW w roku akademickim 2005/2006";

5. Sprawozdanie z działalności Archiwum UKSW w roku $2006^{5}$;

6. Sprawozdanie z działalności Archiwum UKSW w latach 2000-20076;

\footnotetext{
1 Archiwum Uniwersytetu Kardynała Stefana Wyszyńskiego w Warszawie (dalej: AUKSW), Plany i sprawozdania roczne Archiwum UKSW, akta bieżące bez sygnatury archiwalnej. Sprawozdanie to jest załącznikiem do pisma AUKSW-033-1/03 z dn. 29 X 2003 r. i jest odpowiedzią na konieczność stworzenia sprawozdania Rektora UKSW z działalności jednostek dla Ministerstwa Edukacji Narodowej i Sportu.

2 Ibidem. Jest to załącznik do pisma AUKSW-033-1/04 z dn. 30 IX 2004 r. i jest odpowiedzią na konieczność przekazania opracowań cząstkowych do rocznego sprawozdania Rektora dotyczącego jednostek UKSW.

3 Ibidem. Jest to załącznik do pisma AUKSW-033-1/05 z dn. 30 VIII 2005 r. Tak jak w poprzednich przypadkach jest to konieczność wywiązania się z obowiązku jaki nałożyła Ustawa o Szkolnictwie Wyższym, a mianowicie przedłożenia w MENiS-ie rocznego sprawozdania z działalności uczelni. Chodziło głównie o wprowadzenie aktualizacji w danych dostarczonych do poprzedniego sprawozdania Rektora z działalności uczelni.

4 Ibidem. Jest to załącznik do pisma AUKSW-033-1/06 z dn. 22 IX 2006 r. i jest odpowiedzią na konieczność uzyskania przez władze uczelni sprawozdania rocznego jednostki.

5 Ibidem. Jest to załącznik do pisma AUKSW-033-1/07 z dn. 20 IV 2007 r. (na potrzeby Biura Rektora UKSW).

6 AUKSW, Plany i sprawozdania wieloletnie Archiwum UKSW, akta bieżące bez sygnatury archiwalnej. Sprawozdanie to powstało 25 IX 2007 r. jako załącznik do Uchwały nr 1/2007 Rady Archiwum UKSW z dn. 28 IX $2007 \mathrm{r}$.
} 
7. Sprawozdanie z działalności Archiwum UKSW w roku 2007';

8. Sprawozdanie z działalności Archiwum UKSW w roku 2008;

9. Sprawozdanie z działalności Archiwum UKSW za rok 20089;

10. Sprawozdanie z działalności Archiwum UKSW za rok 2009";

11. Sprawozdanie z działalności Archiwum UKSW w latach 2000-2010"1

12. Sprawozdanie z działalności Archiwum UKSW za rok $2010^{12}$;

13. Sprawozdanie z działalności Archiwum UKSW za rok 2011

14. Sprawozdanie z działalności Archiwum UKSW za rok akademicki 2010/2011'14;

15. Sprawozdanie z działalności Archiwum UKSW za rok akademicki 2011/201215;

16. Sprawozdanie z działalności Archiwum UKSW za rok 2012 ${ }^{16}$;

17. Sprawozdanie z działalności Archiwum UKSW za rok 2013 ${ }^{17}$;

18. Sprawozdanie z działalności Archiwum UKSW za rok $2014^{18}$.

Wszystkie sprawozdania sporządzone zostały według podobnego schematu: obejmują sprawy organizacyjne, dane dotyczące personelu, zarządzania majątkiem trwałym uczelni, działalność merytoryczną Archiwum UKSW, kontrole.

Sprawy organizacyjne we wszystkich sprawozdaniach obejmują okoliczności i cel powołania Archiwum UKSW, modyfikowane w trakcie regulaminy i przepisy kancelaryjno-archiwalne, na podstawie których ono działa. A są to obecnie poniższe, uzgodnione z Archiwum Państwowym w Warszawie regulaminy i normatywy kancelaryjno-archiwalne:

\footnotetext{
AUKSW, Plany i sprawozdania roczne Archiwum UKSW, akta bieżące bez sygnatury archiwalnej. Jest to załącznik do pisma AUKSW-033-1/08 z dn. 17 IV 2008 r. (na potrzeby Biura Rektora UKSW do sporządzenia sprawozdania rocznego Rektora z działalności uczelni za 2007 r. dla Ministerstwa Nauki i Szkolnictwa Wyższego.

8 Ibidem. Jest to załącznik do pisma AUKSW-033-1/09 z dn. 15 VII 2009 r. do Rektora UKSW.

9 AUKSW, Rada Archiwum UKSW, akta bieżące bez sygnatury archiwalnej. Jest to załącznik do Uchwały nr 3/2009 Rady Archiwum UKSW z dn. 15 I 2009 r.

10 Ibidem. Jest to załącznik do Uchwały nr 1/2010 Rady Archiwum UKSW z dn. 14 I 2010 r.

11 AUKSW, Plany i sprawozdania wieloletnie Archiwum UKSW, akta bieżące bez sygnatury archiwalnej. Jest to załącznik do Uchwały nr 1/2011 Rady Archiwum UKSW z dn. 2 XII 2011 r.

12 AUKSW, Rada Archiwum UKSW, akta bieżące bez sygnatury archiwalnej. Jest to załącznik do Uchwały nr 4/2011 Rady Archiwum UKSW z dn. 16 XII 2011 r.

13 AUKSW, Rada Archiwum UKSW, akta bieżące bez sygnatury archiwalnej (załącznik do Uchwały nr 1/2012 Rady Archiwum UKSW z dn. 11 I 2012 r.); AUKSW, Plany i sprawozdania roczne z działalności UKSW, akta bieżące bez sygnatury archiwalnej (załącznik do pisma AUKSW-033-1/12 z dn. 18 I 2012 r. do Dyrektora Archiwum Państwowego m.st. Warszawy).

14 AUKSW, Plany i sprawozdania roczne, akta bieżące bez sygnatury archiwalnej. Jest to załącznik do pisma AUKSW-033-2/12 z dn. 23 VIII 2012 r. do Prorektora ds. Finansowych i Naukowych w sprawie sprawozdania rocznego z działalności Archiwum UKSW.

15 Ibidem. Jest to załącznik do pisma AUKSW-033-2/12 z dn. 23 VIII 2012 r. do Prorektora ds. Finansowych i Naukowych w sprawie sprawozdania rocznego z działalności Archiwum UKSW.

16 AUKSW, Rada Archiwum UKSW, akta bieżące bez sygnatury archiwalnej (załącznik do Uchwały nr 1/2013 Rady Archiwum UKSW z dn. 22 II 2013 r.); AUKSW, Plany i sprawozdania roczne Archiwum UKSW, akta bieżące bez sygnatury archiwalnej (załącznik do pisma AUKSW-033-1/13 z dn. 11 III 2013 r.).

17 AUKSW, Rada Archiwum UKSW, akta bieżące bez sygnatury archiwalnej (załącznik do Uchwały nr 1/2014 Rady Archiwum UKSW z dn. 13 I 2014 r.); AUKSW, Plany i sprawozdania roczne Archiwum UKSW, akta bieżące bez sygnatury archiwalnej (załącznik do pisma AUKSW-033-1/14 z dn. 13 I 2014 r. do Prorektora UKSW ds. Finansowych i Infrastruktury oraz Dyrektora Archiwum Państwowego w Warszawie).

18 AUKSW, Rada Archiwum UKSW, akta bieżące bez sygnatury archiwalnej (załącznik do Uchwały nr 1/2015 Rady Archiwum UKSW z dn. 8 I 2015 r.).
} 
1. Regulamin Archiwum Uniwersytetu Kardynała Stefana Wyszyńskiego w Warszawie wprowadzony w życie Zarządzeniem nr 45/2007 Rektora UKSW z dnia 29 listopada 2007 r. w sprawie nadania Regulaminu Archiwum Uniwersytetu Kardynała Stefana Wyszyńskiego w Warszawie;

2. Regulamin udostępniania zasobu Archiwum Uniwersytetu Kardynała Stefana Wyszyńskiego w Warszawie wprowadzony w życie Decyzją nr 13/2002 Rektora UKSW z dnia 29 listopada 2002 r. w sprawie Regulaminu udostępniania zasobu Archiwum Uniwersytetu Kardynała Stefana Wyszyńskiego w Warszawie;

3. Instrukcja kancelaryjna wprowadzona w życie Zarządzeniem Rektora Uniwersytetu Kardynała Stefana Wyszyńskiego w Warszawie nr 5/06 z dnia 21 lutego 2006 r., zatwierdzona przez Dyrektora APW pismem (znak: VI 401-17/06) z dnia 9 lutego 2006 r.;

4. Instrukcja archiwalna wprowadzona w życie Zarządzeniem Rektora Uniwersytetu Kardynała Stefana Wyszyńskiego w Warszawie nr 24/2009 z dnia 29 maja 2009 r., zatwierdzona przez Dyrektora APW pismem (znak: VI 401-25/09) z dnia 14 maja 2009 r.;

5. Jednolity Rzeczowy Wykaz Akt wprowadzony w życie Zarządzeniem Rektora Uniwersytetu Kardynała Stefana Wyszyńskiego w Warszawie nr 11/2009 z dnia 3 kwietnia 2009 r., zatwierdzony przez Dyrektora APW pismem (znak: VI 401-25/09) z dnia 17 marca $2009 \mathrm{r}$.

Poszczególne sprawozdania w sposób przejrzysty pokazują też stan bieżący personelu Archiwum UKSW: kto jest zatrudniony, na jakim stanowisku, jakie ma wykształcenie, doświadczenie, staż. Interesujące z punktu widzenia rozwoju uczelni i polityki jej władz jest strategiczne zagadnienie, a mianowicie pomieszczenia archiwalne, zwłaszcza magazynowe. Jak autor tego artykułu miał okazje przekonać się na różnych konferencjach archiwistycznych w kraju, jest to podstawowe zmartwienie większości archiwów zakładowych, zwłaszcza uczelnianych. Dynamiczny wzrost liczebny uczelni wyższych w latach po transformacji ustrojowej w kraju, a co za tym idzie wzrost liczby studentów, spowodował także przyrost efektu końcowego studiów, tj. teczek studenckich. A te przecież trzeba gdzieś przechowywać, i to jak wiadomo długo (kat. BE50). Ilość i wielkość pomieszczeń przynależnych Archiwum UKSW przez 15 lat jego istnienia, można powiedzieć, dynamicznie ewoluowały, będąc przedmiotem szczególnej troski i zabiegów jego pracowników. Początkowo Archiwum UKSW zajmowało dwa pomieszczenia, znajdujące się w budynku Rektoratu przy ul. Dewajtis 5 w Warszawie: pokój biurowy o powierzchni 7,5 $\mathrm{m}^{2}$ i magazyn archiwalny o powierzchni 78 $\mathrm{m}^{2}$. W roku akademickim 2004/2005 przydzielono archiwum dwa pomieszczenia magazynowe w tzw. Łączniku, o powierzchni 6,5 m² i 10,9 m² (razem 17,4 m²). Pod koniec $2007 \mathrm{r}$. archiwum otrzymało magazyn w budynku nr 18 w kampusie Uczelni przy ul. Wóycickiego 1/3. W 2009 r. Archiwum UKSW przydzielono w tzw. Starym Gmachu przy ul. Dewajtis 5 pomieszczenie na czytelnię oraz dwa nowe magazyny w budynku nr 23 przy ul. Wóycickiego $1 / 3$. Jednak na skutek zmian organizacyjnych w UKSW archiwum musiało w tym samym czasie zwolnić magazyn w budynku nr 18 przy ul. Wóycickiego 1/3. W 2010 r. także jedno z pomieszczeń archiwum w budynku nr 23 przy ul. Wóycickiego $1 / 3$ zostało przeznaczone na inny cel. Tak więc do maja $2011 \mathrm{r}$. archiwum zajmowało pomieszczenia znajdujące się w trzech obiektach UKSW, usytuowanych w Warszawie:

1. w tzw. Starym Gmachu przy ul. Dewajtis 5 - pomieszczenie biurowe, magazyn archiwalny $\left(78 \mathrm{~m}^{2}\right)$ oraz czytelnię (pracownię naukową); 
2. w tzw. Łączniku przy ul. Dewajtis 5 - dwa magazyny $\left(6,5 \mathrm{~m}^{2}\right.$ i $\left.10,9 \mathrm{~m}^{2}\right)$;

3. w budynku nr 23 przy ul. Wóycickiego 1/3 - jeden magazyn o $\mathrm{nr},,-13$ ” $\left(18,75 \mathrm{~m}^{2}\right)$ (liczące obecnie 80 metalowych półek, na których przechowuje się dokumentację niearchiwalną, o kategorii archiwalnej nie wyższej niż B10).

W sumie powierzchnia magazynowa wynosiła wówczas $114,15 \mathrm{~m}^{2}$.

Sytuacja lokalowa Archiwum UKSW uległa istotnej zmianie w maju 2011 r. W wyniku realizacji zaleceń pokontrolnych Archiwum Państwowego m.st. Warszawy z dnia 28 lipca 2009 r. archiwum otrzymało nowy budynek w Kampusie im. Rektora UKSW ks. prof. dr. hab. Ryszarda Rumianka przy ul. Wóycickiego 1/3 w Warszawie (budynek nr 3). Nowy budynek zaadaptowany na potrzeby archiwalne z obszernej auli wykładowej, spełnia wymogi określone w normie PN-ISO 11799:2006. Jego powierzchnia użytkowa to 218,52 $\mathrm{m}^{2}$, kubatura $1000 \mathrm{~m}^{3}$, wymiary w rzucie 24,6 m x 10,7 m, wysokość użytkowa pomieszczeń średnio 3,0 m. Wyżej wymieniony budynek posiada:

1. magazyn na akta - o powierzchni $139,80 \mathrm{~m}^{2}$ (do kwietnia $2015 \mathrm{r}$. z regałami metalowymi przesuwnymi i stacjonarnymi - $855 \mathrm{mb}$., tj. 855 półek);

2. magazyn na dokumentację audiowizualną - o powierzchni 4,03 $\mathrm{m}^{2}$ (z regałami metalowymi stacjonarnymi -15 mb., tj. 15 półek);

3. pracownię naukową (czytelnię) - posiadającą jedno stanowisko dla interesantów $4,03 \mathrm{~m}^{2}$

4. pomieszczenie biurowe wraz z zapleczem socjalnym $-27,82 \mathrm{~m}^{2}$;

5. pomieszczenia techniczne, $\mathrm{w}$ tym m.in. wentylatornię - w sumie $21,09 \mathrm{~m}^{2}$.

Dzięki zastosowanemu, nowoczesnemu systemowi klimatyzacyjno-wentylacyjnemu, w pomieszczeniach magazynowych nowego budynku przez cały czas utrzymywana jest stała temperatura i wilgotność powietrza. Budynek nr 3 jest poza tym skutecznie zabezpieczony na wypadek pożaru lub włamania. Niestety wraz z otrzymaniem budynku nr 3 przy ul. Wóycickiego 1/3, Archiwum UKSW utraciło trzy stare magazyny w kampusie przy ul. Dewajtis w Warszawie (w sumie ok. 600 półek), które przekazano na potrzeby innych jednostek UKSW. Wskutek tego nowy magazyn został założony dokumentacją już powstałą i przekazaną do archiwum. Nowe dopływy zapełniły magazyn w budynku nr 3 do końca $2014^{19}$. Reasumując, ostatnie sprawozdanie podaje w ustępie poświęconym pomieszczeniu archiwalnemu powierzchnię magazynową archiwum $162,58 \mathrm{~m}^{2} 20$.

Od sprawozdania z działalności Archiwum UKSW w roku 2008 pojawia się też informacja o jego współpracy z Naczelną Dyrekcją Archiwów Państwowych w zakresie tworzenia ogólnopolskich internetowych baz archiwalnych: SEZAM (System Ewidencji Zasobu Archiwalnego), IZA (Inwentarze Zespołów Archiwalnych). Ponadto Archiwum UKSW współpracuje i konsultuje różne zagadnienia bieżące z innymi uczelniami i instytucjami publicznymi.

Rezultatem 15-letniej działalności Archiwum UKSW jest jego imponujący zasób, który na koniec 2014 r. stanowiły:

1. Zespół złożony otwarty Uniwersytetu Kardynała Stefana Wyszyńskiego w Warszawie o nazwie „Uniwersytet Kardynała Stefana Wyszyńskiego w Warszawie”, w skład którego wchodzą materiały aktowe z działalności ATK i UKSW w Warszawie z lat

\footnotetext{
19 Zob. Sprawozdanie z działalności Archiwum UKSW za rok 2014 [w:] AUKSW, Plany i sprawozdania roczne Archiwum UKSW, akta bieżące bez sygnatury archiwalnej.

20 Ibidem.
} 
1954-2014 (901,16 mb, w tym 111,79 mb to materiały kategorii A, 789,37 mb to materiały kategorii B);

2. Zbiór fotografii Archiwum UKSW zawierający materiały fotograficzne z lat 1975-2011 (16240 jednostek archiwalnych, dalej: j.a.);

3. Zbiór nagrań Archiwum UKSW zawierający nagrania z lat 1969-1992 (260 j.a.);

4. Zbiór filmów Archiwum UKSW zawierający materiały filmowe z 2001 r. (10 j.a.).

Od sprawozdania rocznego Archiwum UKSW za 2010 r. pojawiają się ogólne dane poświęcone rozwojowi tego zasobu. Najlepiej zobrazuje to poniższe zestawienie tabelaryczne.

Tab. 1. Rozwój Zasobu Archiwum UKSW w latach 2010-2014

\begin{tabular}{|c|c|c|c|c|c|c|c|c|}
\hline $\begin{array}{c}\text { Sprawoz- } \\
\text { danie } \\
\begin{array}{c}\text { Archiwum } \\
\text { UKSW za } \\
\text { rok }\end{array}\end{array}$ & $\begin{array}{c}\text { Ilość } \\
\text { wopły- } \\
\text { Zéw do } \\
\text { UKSw }\end{array}$ & $\begin{array}{c}\text { Ilość } \\
\text { dopływów } \\
\text { do Zbioru }\end{array}$ & $\begin{array}{c}\text { Przyrost } \\
\text { Foku- } \\
\text { mentacji } \\
\text { ogółem } \\
\text { (w j.a.) }\end{array}$ & $\begin{array}{c}\text { Przyrost } \\
\text { doku- } \\
\text { mentacji } \\
\text { ogółem } \\
\text { (w mb) }\end{array}$ & $\begin{array}{c}\text { Dokumen- } \\
\text { tacja aktowa } \\
\text { ogółem (stan } \\
\text { na kon. r. } \\
\text { spr.*) } \\
\text { (w mb) }\end{array}$ & $\begin{array}{c}\text { Dokumen- } \\
\text { tacja aktowa } \\
\text { kat. A (stan } \\
\text { na kon. r. } \\
\text { spr.*) } \\
\text { (w mb) }\end{array}$ & $\begin{array}{c}\text { Dokumenta- } \\
\text { cja audiowi- } \\
\text { zualna kat. A } \\
\text { (stan na } \\
\text { kon. r. spr.*) } \\
\text { (w mb) }\end{array}$ & $\begin{array}{c}\text { Dokumenta- } \\
\text { cja kat. B } \\
\text { (stan na kon. } \\
\text { r. spr.*) } \\
\text { (w mb) }\end{array}$ \\
\hline 2010 & 4 & - & 672 & 7,6 & 506,33 & - & - & - \\
\hline 2011 & 21 & 1 & 10153 & 94,86 & 601,19 & 72,55 & 7,66 & 520,98 \\
\hline 2012 & 49 & - & 10307 & 125,30 & 739,18 & 92,72 & 7,66 & 638,80 \\
\hline 2013 & 42 & - & 6036 & 83,17 & 829,23 & 100,19 & 7,66 & 720,71 \\
\hline 2014 & 41 & - & 5480 & 74,71 & 901,16 & 103,43 & 7,66 & 789,37 \\
\hline
\end{tabular}

*stan na koniec roku sprawozdawczego

Źródło: opracowanie własne

Działalność merytoryczną Archiwum UKSW także najlepiej zaprezentuje poniższa tabela.

Tab.2. Działalność merytoryczna Archiwum UKSW według sprawozdań z lat 2003-2015

\begin{tabular}{|c|c|c|c|c|c|c|c|c|}
\hline $\begin{array}{c}\text { Sprawoz- } \\
\text { danie } \\
\text { Archiwum } \\
\text { UKSW } \\
\text { z roku }\end{array}$ & $\begin{array}{c}\text { Ilość } \\
\text { jednostek } \\
\text { przekazu- } \\
\text { jących }\end{array}$ & $\begin{array}{c}\text { Ilość prze- } \\
\text { kazanych } \\
\text { dopływów }\end{array}$ & $\begin{array}{c}\text { Ilość } \\
\text { przyjętych } \\
\text { jednostek } \\
\text { archiwal- } \\
\text { nych }\end{array}$ & $\begin{array}{c}\text { Rozmiar } \\
\text { przyjętej } \\
\text { dokumen- } \\
\text { tacji } \\
(\mathrm{w} \text { mb) }\end{array}$ & $\begin{array}{c}\text { Kwerendy } \\
\text { Brakowanie } \\
(\mathrm{w} \text { mb) } \\
\text { nakowe } \\
\text { (użyt- } \\
\text { kownicy } \\
\text { zasobu } \\
\text { archiwal- } \\
\text { nego) }\end{array}$ & $\begin{array}{c}\text { Liczba } \\
\text { kwerend na } \\
\text { potrzeby } \\
\text { jednostek } \\
\text { organiza- } \\
\text { cyjnych } \\
\text { UKSW }\end{array}$ & $\begin{array}{c}\text { Kwerendy } \\
\text { społeczne }\end{array}$ \\
\hline $2002 / 2003^{*}$ & 6 & b.d. & 1149 & 20,90 & - & 1 & 552 & b.d. \\
\hline $2003 / 2004^{*}$ & 8 & b.d. & 4804 & 64,20 & - & 12 & 374 & b.d. \\
\hline $2004 / 2005^{*}$ & 10 & b.d. & 4384 & 36,62 & - & 13 & 289 & b.d. \\
\hline $2005 / 2006^{*}$ & 5 & b.d. & 2276 & 29,72 & 15,70 & 7 & 409 & b.d. \\
\hline 2006 & 4 & b.d. & 1511 & 26,55 & $15,70 * *$ & 8 & 370 & b.d. \\
\hline 2007 & 13 & b.d. & 4876 & 67,32 & - & 5 & 629 & b.d. \\
\hline 2008 & 4 & b.d. & 1510 & 11,50 & - & 3 & 296 & b.d. \\
\hline 2009 & 2 & b.d. & 701 & 3,15 & 12,07 & 22 & 278 & b.d. \\
\hline 2010 & 2 & 4 & 672 & 7,60 & - & 4 & 208 & b.d. \\
\hline 2011 & 7 & 22 & 10153 & 94,86 & - & 10 & 230 & b.d. \\
\hline
\end{tabular}




\begin{tabular}{|c|c|c|c|c|c|c|c|c|}
\hline $\begin{array}{c}\text { Sprawoz- } \\
\text { danie } \\
\text { Archiwum } \\
\text { UKSW } \\
\text { z roku }\end{array}$ & $\begin{array}{c}\text { Ilość } \\
\text { jednostek } \\
\text { przekazu- } \\
\text { jących }\end{array}$ & $\begin{array}{c}\text { Ilość prze- } \\
\text { kazanych } \\
\text { dopływów }\end{array}$ & $\begin{array}{c}\text { Ilość } \\
\text { przyjętych } \\
\text { jednostek } \\
\text { archiwal- } \\
\text { nych }\end{array}$ & $\begin{array}{c}\text { Rozmiar } \\
\text { przyjętej } \\
\text { dokumen- } \\
\text { tacji } \\
(\mathrm{w} \mathrm{mb})\end{array}$ & $\begin{array}{c}\text { Kwerendy } \\
\text { naukowe } \\
\text { (użyt- } \\
\text { Brakowanie } \\
\text { kownicy } \\
\text { zasobu } \\
\text { archiwal- } \\
\text { nego) }\end{array}$ & $\begin{array}{c}\text { Liczba } \\
\text { kwerend na } \\
\text { potrzeby } \\
\text { jednostek } \\
\text { organiza- } \\
\text { cyjnych } \\
\text { UKSW }\end{array}$ & $\begin{array}{c}\text { Kwerendy } \\
\text { społeczne }\end{array}$ \\
\hline 2012 & 20 & 49 & 10307 & 125,30 & - & 6 & 260 & 9 \\
\hline 2013 & 13 & 42 & 6036 & 83,17 & - & 11 & 186 & 3 \\
\hline 2014 & 15 & 41 & 5480 & 74,71 & - & 36 & 160 & 3 \\
\hline
\end{tabular}

* rok akademicki

**powtórzone dane ze Sprawozdania z działalności Archiwum UKSW w roku ak. 2005/2006

Źródło: opracowanie własne

Sprawozdania Archiwum UKSW dokumentują też działalność naukową jego pracowników, ich udział czynny i bierny w wielu krajowych, archiwalnych konferencjach, sympozjach, seminariach naukowych (Warszawa, Poznań, Kule k. Częstochowy, Koszalin, Legnica, Łódź, Katowice, Święty Krzyż, Toruń, Kraków). Efektem tego udziału, i nie tylko, były też publikacje naukowe pracowników Archiwum UKSW w różnych periodykach (,Rocznik Mazowiecki”, „Dzieje dawne i nowe”, „Saeculum Christianum”). Sprawozdania świadczą także o działalności dydaktycznej jego pracowników: o przeprowadzonych szkoleniach archiwalnych dla studentów pierwszego roku historii w UKSW, o przeprowadzonych praktykach dla grup studentów specjalizacji archiwistycznej Wydziału Nauk Historycznych i Społecznych UKSW, o zorganizowanych szkoleniach archiwalno-kancelaryjnych dla pracowników UKSW niebędących nauczycielami akademickimi. Warto tu odnotować udział pracowników Archiwum UKSW w pracach nad uczelnianymi przepisami kancelaryjnymi i archiwalnymi (takimi jak instrukcja kancelaryjna, jednolity rzeczowy wykaz akt, instrukcja archiwalna, regulamin archiwum, regulamin udostępniania zasobu archiwum) a także działalność kontrolną i wspomagającą merytorycznie jednostki w tych dziedzinach.

Sprawozdania z działalności Archiwum UKSW dokumentują też kontrole zewnętrzne przeprowadzone w nim w latach 2002, 2005, 2009 i 2013 oraz wewnętrzną - w 2013 r.

Od sprawozdania z działalności Archiwum UKSW za rok 2009 rejestruje się też posiedzenia, jakie odbyła w danym roku sprawozdawczym Rada Archiwum UKSW i podjęte na nich uchwały.

Poza tym sprawozdania te są również świadectwem tytanicznej pracy, jaką pracownicy wykonali przy opracowywaniu akt odziedziczonych po Akademii Teologii Katolickiej w Warszawie. Wiele wysiłku włożono w przegranie z taśm szpulowych na nośnik cyfrowy nagrań dźwiękowych dotyczących ATK, w zeskanowanie przekazanych do Archiwum UKSW materiałów fotograficznych ATK/UKSW i sporządzenie dla nich pomocy ewidencyjnych.

Sporym ułatwieniem w pracy codziennej archiwistów są powstałe w nim i zebrane pomoce archiwalne, takie jak: spisy zdawczo-odbiorcze, wykazy spisów zdawczo-odbiorczych, inwentarz Zbioru nagrań Archiwum UKSW, katalog chronologiczno-rzeczowy Zbioru Fotografii Archiwum UKSW, katalog Zbioru Fotografii Archiwum UKSW z podziałem na negatywy i pozytywy, inwentarz Zbioru Filmów Archiwum UKSW, indeks osobowy Zbioru Filmów Archiwum UKSW. 
Zaprezentowane tutaj sprawozdania roczne i wieloletnie z działalności Archiwum UKSW składane przez jego pracowników, czy to do Archiwum Państwowego w Warszawie, czy to do władz Uczelni, dają bardzo dobry obraz jego pracy. Zawierają część statystyczną z informacjami o ilości i stanie przechowywanych jednostek archiwalnych z podziałem na materiały archiwalne i dokumentacje niearchiwalną, o ilości przejętych jednostek archiwalnych w rozbiciu na komórki organizacyjne, o ilości wybrakowanej dokumentacji niearchiwalnej, wreszcie o ilości udostępnionych oraz wypożyczonych akt. Część opisowa tych sprawozdań to głównie sygnalizowanie problemów lokalowych Archiwum UKSW, kontrole w nim przeprowadzone i związane z nimi zalecenia i ich realizacja. Zaznaczyć należy, iż dynamikę działania Archiwum UKSW zawdzięcza też wsparciu i działaniu Rady Archiwum, jego uchwałom z posiedzeń, jak również współpracy z innymi tego typu jednostkami w kraju, choćby poprzez udział w konferencjach naukowych i bieżący kontakt ze środowiskiem archiwistów w Polsce.

Podsumowując, Archiwum UKSW w trakcie swojej działalności ugruntowało dobitnie swoją pozycję w uczelni, realizując swój podstawowy cel: gromadzenie dokumentacji po upływie określonego $\mathrm{w}$ instrukcji kancelaryjnej czasu jej przechowywania $\mathrm{w}$ jednostkach organizacyjnych. Archiwum to ma bowiem spełniać dwie podstawowe funkcje: odciążać poszczególne jednostki organizacyjne uczelni od dokumentacji, która jest już zbędna do bieżącego urzędowania, ale której okres obligatoryjnego przechowywania jeszcze nie upłynął oraz zabezpieczać i przechowywać gromadzone w nim cenne materiały archiwalne. Świadomość posiadania tak wartościowej, zebranej dokumentacji, z punktu widzenia choćby historycznego, powinna być stale obecna przy podejmowaniu decyzji na rzecz tej szacownej instytucji uczelni.

\section{The operation of the Cardinal Stefan Wyszyński University (Warsaw) archive based on its reports from 2003 to 2015 Summary}

The 15th anniversary of the establishment of the Cardinal Stefan Wyszyński University (UKSW) archive is a good moment to reflect on its operation. Its annual reports enable us to recognize the scale and quality of the archive's operation. Reports prepared between 2003 and 2015 for various purposes and authorities show how the archive has fulfilled its basic duties.

The quality of UKSW's archive is monitored by the State Archive in Warsaw. As a interfaculty unit of UKSW, the archive also comes under the authority of one of the University's deputy vice-chancellors. The archive mainly reports to these principal bodies on an annual basis. The archive holds the records of the Warsaw Theological Academy which was later transformed into UKSW.

Keywords: Archive, reporting, reports, documentation, records, archival material, archive record

Nota o Autorze: Roman Poletyło: absolwent Wydziału Kościelnych Nauk Historycznych i Społecznych Akademii Teologii Katolickiej w Warszawie, obecnie pracuje w Archiwum Uniwersytetu Kardynała Stefana Wyszyńskiego w Warszawie. 